\title{
DOSSIÊ
}

\section{LEITURAS SOBRE OS TIMBIRA}

\section{READINGS ON THE TIMBIRA PEOPLES}

\author{
Elizabeth Maria Beserra Coelho* \\ Odair Giraldin** \\ William Fisher***
}

\section{Introdução}

Os artigos que compõem o presente dossiê foram produzidos no contexto da sexta edição do Seminário Temático Timbira, que se realizou de 14 a 18 de dezembro de 2015 , intitulado "Povos Timbira: Educações e Conhecimentos" ${ }^{1}$. 0 objetivo do referido seminário foi dar continuidade à interlocução entre pesquisadores, iniciada em sua primeira edição em 2005, visando a oportunizar e enriquecer diálogos travados entre seus participantes. 0 tema central do encontro foi a educação e os conhecimentos timbira em seus mais variados contextos.
O Seminário Timbira originou-se de uma parceria estabelecida entre o Brasil e os Estados Unidos em 2005. Foi construído a partir do encontro de orientandos da Profa. Dra. Elizabeth Maria Beserra Coelho, da UFMA, com o pesquisador Dr. William H. Crocker, em trabalho de campo entre os Ràmkokamekra/Canela. Esse contato inicial serviu como ponte para o estabelecimento de relações de colaboração e troca que vieram a dinamizar a pesquisa sobre os povos Timbira.

A iniciativa procurou tornar disponivel ao público e aos estudiosos das culturas Jê o acervo de material colhido por pesquisadores do National Museum of Natural History

\footnotetext{
* Doutora em Sociologia pela Universidade Federal do Ceará (UFC). Professora Titular da Universidade Federal do Maranhão (São Luís/MA/BR), dos Programas de Pós-Graduação em Ciências Sociais e em Políticas Públicas. betabeserra@hotmail.com.

*** Doutor em Ciências Sociais pela Universidade Estadual de Campinas (UNICAMP). Professor associado I da Fundação Universidade Federal do Tocantins - UFT (Palmas/TO/BR). giraldin@uft.edu.br.

*** Doutor pela Universidade de Cornell. Professor no Departamento de Antropologia da College of William and Mary (Virgínia/USA), também é pesquisador associado da Smithsonian Institution. whfisher@wm.edu.

1. Financiado por meio do Edital FAPEMA № 02633/15AREC e pela Timbira Research and Education Foundation. Contou também com a colaboração financeira da Universidade Federal do Maranhão (UFMA) e da Universidade Federal do Tocantins (UFT).
} 
da Smithsonian Institution, principalmente o Dr. William H. Crocker mas também outros pesquisadores que participaram em sucessivos trabalhos de campo. Pensou-se que as coleções constituíam um recurso que poderia ser aproveitado regionalmente. Nesse foco regional, o aproveitamento real desse material só poderia ser feito se inserido numa rede de pessoas e instituições indígenas e não indígenas. Assim, uma parte importante da iniciativa consistia em promover a profissionalização de pessoas indígenas e não indígenas e um lugar para tal, onde o intercruzamento e crescimento orgânico de um diálogo poderia florescer. A busca de interesses comuns, de temas de pesquisa, do fomento de redes pessoais e profissionais, do etnodesenvolvimento e do desenvolvimento regional só seria possível em um contexto que apresentasse a possibilidade de colaboração e troca. Dessa necessidade surgiu a organização de um Seminário Temático Timbira. É claro que o sucesso do seminário seria apenas parcial enquanto não existissem melhores condições sociais de pôr em prática o ideal de uma sociedade participativa e democrática. No entanto, o seminário representa uma experiência inédita no Brasil.

0 acordo de colaboração efetivou-se por meio de um convênio assinado entre a Universidade Federal de Maranhão (UFMA), com o grupo de pesquisa Estado Multicultural e Políticas Públicas, coordenado pela Prof. ${ }^{a}$ Dr. ${ }^{a}$ Elizabeth Maria Beserra Coelho, e a Timbira Research and Education Foundation, uma organização sem fins lucrativos presidida à época pelo Dr. William H. Crocker, do National Museum of Natural History da Smithsonian Institution, pesquisador há mais de cinquenta anos do povo Ràmkokamekra/Canela, um dos povos indígenas de língua Jê-Timbira que vivem no Maranhão.
Um dos objetivos do convênio é a cooperação científica e acadêmica entre as duas instituições por meio do intercâmbio entre pesquisadores, estudantes e professores, indígenas e não indígenas, para a manutenção e continuação da pesquisa entre os povos Timbira. Outro objetivo estabelecido no convênio é garantir acesso ao material etnográfico, guardado e curado na Smithsonian Institution, recolhido entre os Ràmkôkamekra/Canela, tendo a UFMA se responsabilizado por receber cópias desse material, cuidar delas e torná-las acessíveis aos interessados: pesquisadores, professores, estudantes (indígenas e não indígenas), os Timbira e o público em geral.

O Seminário Timbira vem se consolidando a cada edição como espaço de estímulo e formação de novos pesquisadores. Ao longo das suas edições, muitas pesquisas foram estimuladas e desenvolvidas, outras surgiram e tiveram continuidade, e vários pesquisadores foram formados em nível de graduação, mestrado e doutorado. Alguns estágios pós-doutorais também se efetivaram em decorrência dessa parceria.

0 primeiro Seminário ocorreu em 2005 na UFMA, com a participação de 22 pesquisadores entre graduandos, mestrandos, mestres e doutores. Entre os pesquisadores, estava a antropóloga Maria Elisa Ladeira, uma das fundadoras do Centro de Trabalho Indigenista (CTI), organização não governamental que atua junto aos povos Timbira há quase quarenta anos, em especial por meio do Programa Timbira. Uma das ações desse programa foi a criação do Centro Timbira de Ensino e Pesquisa Pënxwyj Hëmpejxà.

A partir do I Seminário, ficou estabelecido que os posteriores aconteceriam bianualmente. 0 II Seminário ocorreu em 2007, também na UFMA. Nesse, o objetivo principal foi homenagear o pesquisador Dr. 
William H. Crocker pelos seus cinquenta anos de pesquisa entre os Ràmkôkamekral Canela. Esse segundo seminário ampliou a rede de contato entre pesquisadores sobre os Timbira, envolvendo professores pesquisadores de outras instituições. Foram convidados a participar do evento o Prof. Dr. Júlio Cesar Melatti, da Universidade de Brasília (UnB), pesquisador do povo Krahô, além de um Ràmkôkamekra/Canela. 0 evento contou com a participação de 14 pesquisadores entre graduandos, mestrandos, mestres e doutores.

A terceira edição do Seminário, realizada em 2009, inaugurou a participação dos Timbira na condição de pesquisadores, apresentando pesquisas desenvolvidas por eles junto aos seus povos. Dois pesquisadores Timbira apresentaram seus trabalhos. Ambos cursavam, naquela ocasião, o curso de Licenciatura Intercultural da Universidade Federal de Goiás (UFG).

Na quarta edição, em 2011, ampliou-se o número de povos Timbira participantes no evento, havendo representantes de quase todos os povos Timbira. 0 Seminário Timbira foi se tornando um espaço favorável para o fomento da discussão sobre os povos Timbira a partir da interação entre o olhar dos próprios Timbira com o dos pesquisadores não indígenas.

O V Seminário Temático Timbira ocorreu em 2013 com o objetivo de realizar uma retrospectiva dos seminários anteriores e fortalecer a formação de novos pesquisadores sobre os povos Timbira. Mais uma vez ampliou-se, naquela edição, o número de povos Timbira participantes do evento, havendo membros de cada povo Timbira, exceto os
Krepỳm catejê, que não puderam comparecer. Com isso, criou-se uma oportunidade de diálogo amplo sobre os temas pesquisados relacionados a esses povos.

A partir da quinta edição, o Seminário teve uma reconfiguração em sua organização. Até o IV Seminário, era a Prof. ${ }^{a}$ Dr. ${ }^{a}$ Elizabeth Coelho a principal organizadora do evento. A partir da quinta edição, o seminário teve ampliada sua comissão organizadora, incluindo professoras/pesquisadoras dos campi de Grajaú e São Bernardo (UFMA), alunos do Programa de Pós-Graduação de Ciências Sociais (PPGSOC-UFMA), a Universidade Federal do Tocantins (UFT) por meio do Núcleo de Estudos e Assuntos Indigenas, e a instituição norte-americana William \&t Mary College (EUA, Virgínia).

A sexta edição, realizada em 2015, foi promovida pelos grupos de pesquisa Estado Multicultural e Políticas Públicas (da UFMA) e Núcleo de Estudos e Assuntos Indígenas (NEAI, da UFT) ${ }^{2}$, e pela Timbira Research and Education Foundation (EUA). Contou com a colaboração efetiva e o apoio do Centro de Trabalho Indigenista (CTI). Nessa edição, participaram da comissão organizadora representantes dos povos Timbira. 0 referido Seminário aconteceu nas dependências do Centro Timbira de Ensino e Pesquisa Pënxwyj Hëmpejxà, localizado em Carolina MA. Nesse Seminário objetivou-se construir um amplo fórum de diálogo equitativo de debate sobre a produção de conhecimentos sobre e com os povos indígenas falantes de línguas classificadas como Timbira.

Walter Mignolo (2003), ao focalizar a subalternização de saberes desqualificados 
pelos processos de colonização, propõe a categoria "diferença colonial" objetivando dar conta de novas formas de conhecimento que denomina "pensamento liminar", para criticar a conformação epistêmica predominante tanto nas ciências sociais como na área dos estudos culturais. Nessa linha vem se dando a inserção dos pesquisadores indígenas no Seminário Timbira e no dossiê que ora trazemos a público. 0 conceito de antropologia como um diálogo entre culturas das Américas também se deve ao trabalho de Tedlock e Mannheim (1995). Posey (1983), nos seus trabalhos com os Kayapó, já tinha colocado o fracasso do desenvolvimento nacional a menos que fosse possivel construir uma ponte entre saberes diferentes. Ao lado das teorias da diferença de Mignolo, havia também análises históricas que apontavam a necessidade de abrir um espaço como o Seminário Timbira. Por um lado, a historiografia mostrava que tanto as sociedades indígenas quanto as sociedades nacionais eram produtos de processos históricos comuns (FERGUSON; WHITEHEAD, 1991). Por outro, os estudos "micro-históricos" revelavam o encontro de muitos agentes diferentes e de fatores complexos em que o ecossistema, o Estado e mudanças populacionais condicionaram a vida indígena, e realçavam a necessidade de considerar muitos níveis de causalidade (COIMBRA et al., 2004).
Um sobrevoo da literatura produzida sobres os povos Timbira revela mudanças de foco ao longo dos anos. As contribuições mais recentes provindas do Seminário tendem focalizar uma gama de temas que estão ligados a ritual e cerimônia, às instituições locais e à escola, em conexão com o conhecimento e o saber, à saúde e ao território. Resta saber como esse conjunto de temas vai evoluir, na medida em que o seminário temático continua fomentando a pesquisa e o diálogo entre os participantes.

\section{Os Timbira na literatura}

As primeiras leituras sobre os Timbira foram feitas por Raimundo José da Cunha Mattos (1824), Francisco de Paula Ribeiro (1841), Cândido Mendes de Almeida (1852) e Nimuendajú (1944). Nimuendajú classificou-os como Timbira Orientais e Timbiras Ocidentais. Os Timbira Orientais seriam os que viviam nos cursos inferiores dos rios Mearim e Pindaré no Maranhão: Canela Ràmkokamekra, Canela Apaniekrá, Krĩkati, Gavião/Pykopjêe, Parkateyêe e Krenyê, além dos Krahô que viviam a leste do rio Tocantins, no antigo norte de Goiás. Como Timbira Ocidental, Nimuendajú classificou aquele povo que vivia a oeste do Tocantins, os Apinajé (NIMUENDAJÚ, 1944). 


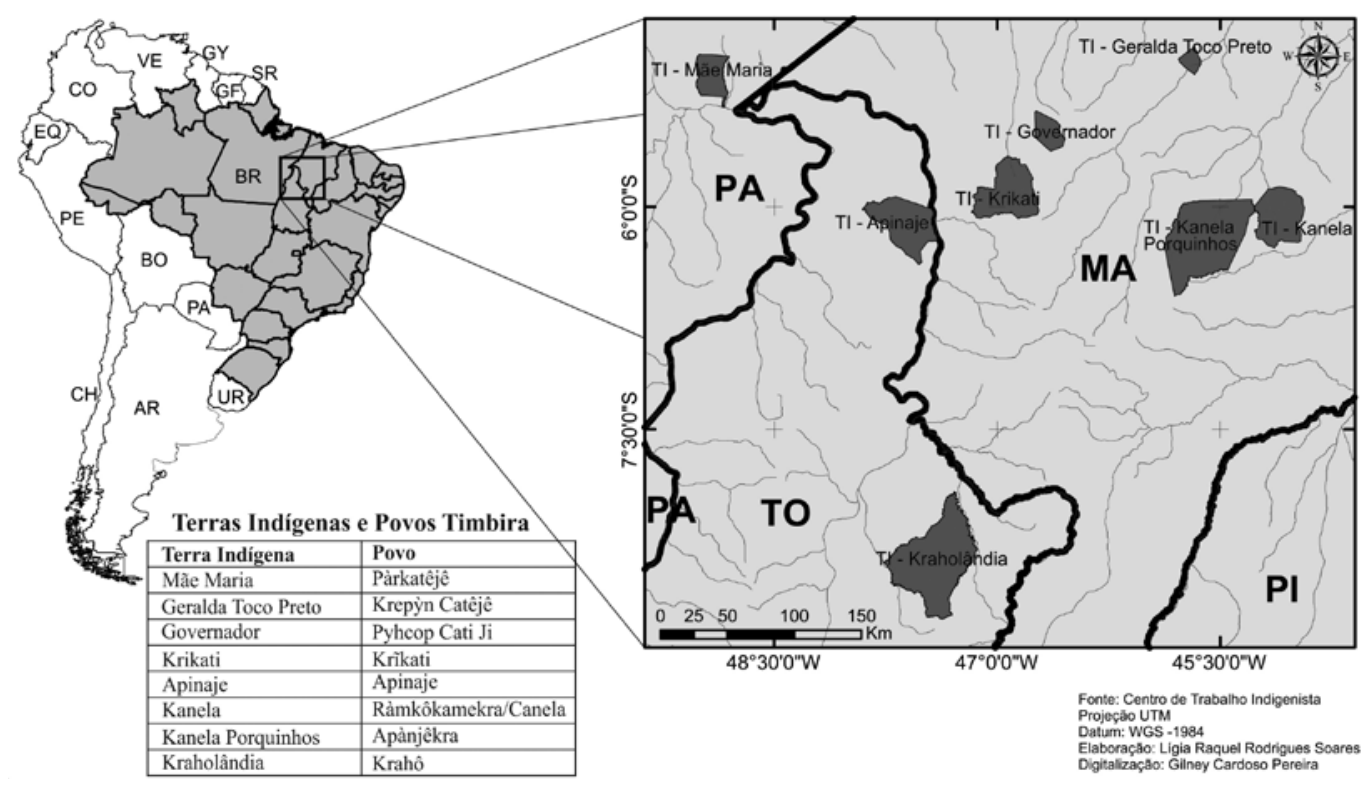

Foi ainda Nimuendajú (1944, §1, p. 1) quem identificou a região limitada ao norte pelo curso do rio Gurupi, a leste pelo curso médio do Itapecuru e seus afluentes, ao sul pelo rio Balsas e a oeste pelo rio Tocantins, desde a desembocadura do rio Manoel Alves Grande até bem abaixo da desembocadura do Araguaia, como sendo o "território" de um total de quinze povos Timbira ${ }^{3}$ que habitavam essa região até o século XIX. Segundo Oliveira (2006), embora constituindo culturas adaptadas ao ambiente do Cerrado, alguns Timbira, espontaneamente ou por pressões das guerras interétnicas contra outros povos indigenas e agentes das frentes expansionistas, deslocaram-se para áreas florestais entre o Grajaú e o Mearim, e entre o Tocantins e o Gurupi.
Francisco de Paula Ribeiro (1841, p. 186), ao fazer referência aos Timbira, afirmou: "Seus costumes geraes diversificam em pouco; e de ordinário, na privada linguagem, que dissemos pertencer a cada uma das acções, se acha aquela diferença trivial que a distancia de umas a outras povoaçoens da mesma raça lhe permite" (RIBEIR0, 1841, p. 186).

Alguns desses povos foram considerados extintos. Ribeiro (1979, p. 57) afirma que somente quatro desses povos teriam alcançado o século XX e argumenta que o principal responsável por essa dizimação teria sido a frente pastoril que veio ocupar o "território" dos Timbira. Acrescenta que os Timbira só tiveram paz quando o governo imperial se interessou pelo que era então

3. 1) Timbira de Araparyty; 2) Kreyé de Bacabal; 3) Kokóekamekra; 4) Kreyé de Cajuapara; 5) Kre'pumkateye;

6) Pukobyê; 7) Krikateye; 8) Gaviões da Mata; 9) Apanyekra; 10) Ramkokamekra; 11) Kenkateye; 12) Krahó;

13) Ća'kamekra; 14) Porekamekra; 15) Apinayé, além de outras “tribos extintas". 
denominado "pacifıcação" e que implicava o aldeamento dos povos indígenas.

No entanto, temos observado em tempos recentes, no Maranhão, dinâmicas de lutas por reconhecimento étnico e por território empreendidas por alguns povos indígenas que haviam sido considerados extintos. Esse é particularmente o caso do povo Krenyê, cuja língua foi classificada como timbira, que foi abordado no artigo de Almeida e Figueiredo Júnior presente neste dossiê.

Após Nimuendajú, alguns antropólogos, também estrangeiros, realizaram investigações sobre os Timbira, como o fez William H. Crocker, desde 1957, (CROCKER, 1990) com os Ràmkôkamẽkra/Canela, abordando parentesco, ritual e sexualidade. Jean Carter Lave (1967) e Dolores Newton (1974) estudaram os Krikati. Enquanto a primeira dedicou-se a analisar a onomástica, a segunda analisou e reuniu um grande acervo da cultura material Krikati e Pyhcop catiji/Gavião. Esse acervo está conservado na Smithsonian Institution, em Washington (EUA).

Um grande investimento de pesquisa foi desenvolvido nos anos 1960, quando David Maybury-Lewis formulou o projeto Harvard-Brasil Central para estudos sistemáticos dos povos de língua Jê. Esse projeto foi realizado de 1962 a 1966, articulado a outro projeto empreendido por Roberto Cardoso de Oliveira, o "Estudo comparativo das sociedades indígenas do Brasil”. Dos pesquisadores desse projeto, dois brasileiros pesquisaram povos Timbira: Roberto DaMatta (1976), que pesquisou os Apinajé, e Júlio César Melatti (1972), os Krahô.

Seguindo pistas e dados etnográficos pouco claros de Curt Nimuendajú, que, por exemplo, tinha admitido a presença de metades matrilineares exogâmicas entre os índios Canela, Crocker não as confirmou, assim como os demais pesquisadores do Projeto Harvard-Museu Nacional não as encontraram entre os demais Timbira. Verificou-se a presença de grupos ou metades de caráter ritual, não ligados à unilinearidade ou a qualquer tipo de regra matrimonial. Roberto DaMatta também não confirmou a presença de quatro grupos kyjê entre os Apinajé que se ligariam por um sistema matrimonial anômalo, com trocas matrimoniais entre membros dos grupos de tal maneira que os homens de um desses grupos (A) se casariam com as mulheres de apenas um outro grupo (B), cujos homens (B) se casariam com as mulheres de um terceiro (C), sendo que homens de C se casariam com mulheres do último grupo (D) e os homens deste se casariam com mulheres do primeiro (A), fechando assim o circuito.

As pesquisas realizadas pelo projeto Harvard Brasil Central foram importantes porque questionaram os dados etnográficos disponíveis e mostraram que a transmissão de nomes pessoais, ligados a papéis rituais (entre os Timbira Orientais), contrapostos às evitações rituais que ligam os indivíduos relacionados pela procriação (os resguardos pela consubstanciação das relações entre genitores), estava relacionada às relações de parentesco internas à família elementar e às demais relações, ligadas à esfera social da pessoa. Tais conclusões foram importantes para o desenvolvimento posterior das reflexões sobre uma característica forte das sociedades das terras baixas da América do Sul: a noção de pessoa e a construção do corpo. Além disso, a etnografia comparada fez importantes contribuições para a compreensão da organização dual e do dualismo. Mostrou como o pensamento dual fazia parte da organização complementar do público e do privado e integrava-se no cotidiano da vida. Nisso ajudou 
a entender como, para os povos Jê, o dualismo serve como teoria tanto da sociedade quanto da pessoa. Com esse insight, os pesquisadores do projeto Harvard-Museu Nacional adiantaram muito o estudo comparado da organização social dos Jê. Eles também argumentaram contra uma abordagem genealógica de parentesco. Para eles, a terminologia de parentesco só podia ser compreendida por meio do seu uso na vida cotidiana e cerimonial, e dos conceitos culturais que tornaram o uso inteligível para os nativos.

Depois desse grande projeto, as pesquisas direcionadas aos Jê ou aos Timbira ocorreram de forma pontual e dispersa no tempo. Em 1978, Manuela Carneiro da Cunha (1978) publicou Os mortos e os outros, no qual aborda a noção de alteridade na forma como os Krahô lidam com seus mortos e com a ideia da morte.

Nos anos 1980, algumas dissertações de mestrado foram produzidas sobre os Timbira. Maria Helena Barata (1981) pesquisou os Pyhcop catitij/Gavião, abordando suas relações sociopolíticas por meio da noção de drama social. Maria Elisa Ladeira (1982) abordou o parentesco timbira, argumentando que a troca de nomes levaria a uma troca de cônjuges em razão de os nomes serem "propriedades" das famílias extensas e que, para promover o retorno dos nomes, as mulheres manipulariam os arranjos matrimoniais. Iara Ferraz (1984) investigou os Gaviões Parkatjê. Nesse mesmo ano, Gilberto Azanha (1984) escreveu sobre a forma Timbira, fazendo reflexões sobre as terminologias de nominação dos povos Timbira, explicando, a partir delas, as formas de relacionamento entre os diversos povos.

No século XXI, novas produções sobre os povos Timbira vieram a público, princi- palmente na forma de teses e dissertações. Sobre os Apinajé, Giraldin (2000) produziu uma tese de doutorado com as temáticas de história, sistema de nominação e cosmologia, mostrando que o sistema de nominação está ligado à amizade formal e que esta cria condições para a existência de um sistema preferencial de trocas matrimoniais entre os Apinajé. Sobre o mesmo povo, Raquel Rocha (2002) escreveu uma dissertação de mestrado abordando as relações de gênero. Ela também produziu uma tese de doutorado (ROCHA, 2012) tratando das transformações sociais e de questões de etnodesenvolvimento entre os Apinajé.

A temática do contato foi objeto da dissertação de Thiago Antônio Machado Ávila (2004), o qual tratou do acesso aos recursos genéticos por meio da pesquisa, via conhecimentos tradicionais, e das relações interétnicas no início do século XXI.

Os Apànjekra/Canela foram objeto de estudo da dissertação de Luiz Augusto Sousa do Nascimento (2009), que fez uma análise de conflitos faccionalistas que observou na aldeia Porquinhos, por meio da noção de drama social.

0 mesmo povo foi investigado por Bruno Nogueira Guimarães (2012). Em sua dissertação de mestrado, o autor tratou do processo de demarcação da Terra Indígena de Porquinhos, ocorrido entre as décadas de 1970 e 1980 visando a estabelecer a reserva habitada pelos índios Apànjekra/Canela. A partir de uma análise etnográfica dos arquivos da FUNAI e de seus documentos, ele busca mapear os agentes envolvidos na efetivação da terra indígena, tratando das controvérsias a respeito de suas fronteiras, da ação do Estado e da legislação. Em sua tese de doutorado (GUIMARÃES, 2017), tratou da concepção do povo indígena Apànjekra/Canela sobre a população não 
indígena, tanto aquela que vive próxima ao seu território e com quem mantém contato cotidiano quanto os "brancos" com os quais possuem relações indiretas, mas que se fazem presentes por meio de políticas públicas acessadas por eles. 0 autor parte da análise do corpus mitológico Apànjekra, de sua concepção sobre o parentesco e da diferença entre os indígenas e os "brancos”, analisando também a percepção nativa do Programa Bolsa Família (PBF), que os Apànjekra tomam como uma das vias principais de acesso aos bens industrializados. Seu argumento é que o dinheiro e a atuação dos agiotas que intermedeiam o acesso dos indígenas ao PBF levantam um problema ético para os Apànjekra, tocando diretamente os processos de constituição da pessoa e do parentesco ao subverter os princípios econômicos nativos.

Numa série de artigos focalizando os ritos da aldeia Canela/Ràmkôkamẽkra, pesquisadores alemães, o antropólogo Jakob Mehring e o educador físico Jürgen Dieckert (1990, 1992, 1993), contestam a premissa de que as metades e outras divisões organizacionais nas sociedades Jê são projeções de uma visão dualista do cosmos. Em contraposição, postulam que atividades coletivas, notadamente as corridas de tora e os cantos, são projetos do grupo como um todo, conscientemente concebidos como veículos para assegurar a felicidade e o bem-estar de todos. Nessa perspectiva, a rejeição dos Canela a qualquer separação entre corpo, espírito e outras entidades materiais coexiste com outro pressuposto: o de que a atividade coletiva é necessária para gerar a unidade contínua entre corpo e espírito, que é patente numa comunidade saudável e potente. Uma expressão dessa ótica está presente em Mehringer, Kowalski e Dieckert (2003) e em Kowalski (2003). Es- ses autores conseguiram canalizar recursos alemães para a aldeia Canela com a finalidade de estabelecer projetos de desenvolvimento, inclusive o treinamento de um dentista e a instalação de uma clínica para tratamento dentário. A tese de doutorado de Kowalski (2008) apresenta uma reflexão sobre o pensamento indígena relativo a projetos de ajuda, privilegiando o ponto de vista indígena. Ele conclui que aquilo que os "brancos" costumam considerar como o fracasso desses projetos poderia ser fruto da capacidade indígena de se impor no âmbito dos projetos no sentido de assegurar a manutenção da alteridade segundo critérios nativos.

Ocorreram, também, iniciativas de pesquisas que articularam pesquisadores desenvolvendo investigações em um mesmo povo ou em diferentes povos, como no âmbito do grupo de pesquisa Estado Multicultural e Políticas Públicas da UFMA. Em decorrência do convênio desse grupo de pesquisa com a Timbira Research and Education Foundation, multiplicaram-se as pesquisas sobre os Timbira na última década. Os Ràmkôkamẽkra/Canela foram foco privilegiado dessas investigações.

A investigação realizada por Adalberto Rizzo de Oliveira (2006) durante seu doutorado esteve voltada para as formas pelas quais os Canela, inspirados pela leitura de seus movimentos messiânicos, relacionam-se com o indigenismo de Estado, especialmente com as estratégias de desenvolvimento. Buscou analisar os processos de mudança associados aos projetos e programas de desenvolvimento regional e aos projetos "locais", bem como às manifestações sociorreligiosas e demais respostas emitidas pelos Ràmkôkamẽkra/Canela em relação aos processos associados à dominação. Essa pesquisa tomou como referên- 
cia o processo por meio do qual se operou uma série de transformações econômicas e sociais em toda a Amazônia Oriental, especificamente no estado do Maranhão, a partir dos anos 60 do século XX. Focaliza conflitos, disputas e mediações inerentes a esse processo envolvendo diferentes atores vinculados ao campo indigenista no centro-sul maranhense: agentes tutelares e de desenvolvimento, criadores e pequenos agricultores locais, lideranças políticas e coletividades regionais, além dos próprios Ràmkôkamẽkra/Canela. A pesquisa buscou, também, conhecer os modos de compreensão e as respostas do povo Ràmkôkamẽkral Canela diante dos processos de mudança sociocultural relacionados ao desenvolvimento deflagrados nas últimas décadas e seus impactos no centro-sul maranhense. A emergência de movimentos sociorreligiosos tem sido uma das maneiras pelas quais os Ràmkôkamẽkra/Canela têm se expressado diante desses processos, especialmente ao longo do último meio século, tendo em vista a redefınição das relações intersocietárias na região sob a égide do desenvolvimento. Os movimentos sociorreligiosos têm emergido em diferentes regiões do Brasil, em momentos históricos específicos e sob diferentes motivações. Inspirados nas referências mítico-religiosas comuns aos grupos Timbira, esses movimentos levaram a respostas específicas em relação às compulsões advindas do contato. Os movimentos sociorreligiosos Ràmkôkamẽkra/Canela, para esse autor, intrigam pela sua persistência e periodicidade. Assim, cerca de duas décadas após a eclosão do "clássico" movimento messiânico Canela de $1963^{4}$, novos movimentos e manifestações sociorreligiosas emergiram nesse povo até o final século XX, o que revela uma perspectiva de sua continuidade em relação a esse povo timbira.

Algumas investigações estiveram articuladas ao projeto "Estado Poliétnico e Políticas públicas: as políticas indigenistas”, coordenado por Elizabeth Coelho no âmbito do GPEMPP-UFMA e financiado pelo CNPq. Tomando como referência a implantação de projetos específicos junto aos Ràmkôkamẽkra/Canela, foi realizada por Gomes (2007), em seu mestrado, uma investigação que procurou identificar as representações construídas por esse povo sobre a instalação da luz elétrica em sua aldeia, ocorrida em 2005. A instalação da energia elétrica foi analisada no contexto do desenvolvimento do Projeto de Combate à Pobreza Rural no Maranhão (PCPR), financiado pelo Banco Mundial. Segundo Gomes (2007), o PCPR classificou os povos indígenas como segmentos pobres e marginalizados da sociedade maranhense, expressando uma concepção de pobreza relacionada à carência de bens materiais e de conhecimentos produzidos pela matriz racional/ocidental. Gomes conclui que os Ràmkôkamẽkra/Canela, ao demandarem a instalação da rede elétrica em sua aldeia, expressaram uma decisão pautada pela colonialidade do poder (MIGNOLO, 2003). Historicamente, os Ràmkôkamẽkra/Canela foram ensinados a perceber sua realidade como "atrasada", "pobre", "subdesenvolvida”, e a ver o mundo dos brancos como signo de "progresso" e "desenvolvimento". A luz elétrica era representada como um passo em direção ao "progresso". Gomes (2007) aponta que a tensão marcou todo o processo de decisão pela implantação da 
energia elétrica. Percebida como um presente enviado por Awkhê, a luz elétrica tem representado uma ameaça à realização de rituais tradicionais, que passam a concorrer com a televisão, ao mesmo tempo em que significa a possibilidade de aquisição de novos conhecimentos do mundo dos "brancos", acessíveis através da televisão.

No contexto do mesmo projeto, foram desenvolvidas pesquisas que objetivaram perceber como o povo Canela representa a educação escolar, por meio da observação da escola da aldeia e da dinâmica de migração para a cidade em busca da continuidade dos estudos. A investigação conduzida por João Marcelo Macena (2007) durante o mestrado pretendeu interpretar as representações Canela sobre a escola da aldeia e identificar em que medida esse povo tem conseguido se apropriar dessa instituição e ressignificá-la segundo seus interesses. Segundo Macena (2007), o espaço escolar entre os indígenas atualmente representa um local de constante tensão entre assimilação e o respeito cultural. Dentro desse quadro, além de um intenso choque cultural existe o choque entre a demanda dos indígenas e a oferta do Estado, que nem sempre atende às especificidades dos primeiros, por mais que atualmente eles tenham voz e a legislação dê suporte para que sejam propostas políticas de educação apropriadas às suas realidades linguísticas e culturais. A escola, ao ser trazida para dentro de uma nação indígena, mesmo com a proposta de ser uma instituição intercultural, traz consigo uma série de mudanças com as quais os Canela têm que lidar e às quais, na maioria das vezes, têm que se adaptar. Além dos fatores de ordem cultural, a escola traz consigo um verdadeiro "kit burocrático". São contratações de professores e o seu assalariamento, a criação de associações para captação de recursos, a prestação de contas das atividades da escola por meio de relatórios, entre outras ações.

Porém, existe também o outro lado da moeda. Muitas dessas ações burocráticas acabam sendo alteradas pelas realidades indígenas com as quais se confrontam. A presença da escola entre os Ràmkôkamẽkral Canela, conforme Macena (2007), está diretamente ligada a uma questão relacional maior. Trata-se de uma rede de aprendizado que é vista pelos indígenas como uma forma de comunicação e inserção no mundo dos kupen. Essa inserção não significa a perda das raizes culturais e é vista apenas como uma via de estabelecimento de relações em um contexto que transcende os limites da aldeia e, atualmente, possui dimensões globais. Os Ràmkôkamẽkra/Canela buscam na escola essa via de acesso, às vezes repetindo o discurso ocidental de que a educação escolar trará benefícios materiais - "subir na vida". Buscam uma educação de qualidade que não traga alterações radicais no seu modo de vida. Macena (2007) afırma que os Ràmkôkamẽkra/Canela ainda não se apropriaram da instituição escolar de forma que ela se configure uma "escola indígena", no sentido de assumirem a sua administração, controlando-a de dentro. A escola na cosmologia local é vista como parte do mundo não indígena, provedor. Retomando a afırmação de que a escola "é coisa de kupen”, os Ràmkôkamẽkra/Canela estariam exercendo uma distância desejada entre a sua realidade cultural e uma instituição alienígena, tentando não se envolver de maneira ativa com ela. Isso corresponde a uma forma de resistência, pois, ao limitar a influência mútua entre os dois mundos, eles estariam buscando uma forma de usufruir da instituição escolar sem que ela se torne parte integrante, por completo, de seu universo sociocultural. 
Mônica Ribeiro Moraes de Almeida (2009) também buscou analisar a relação dos Ràmkôkamẽkra/Canela com a instituição escolar em sua dissertação de mestra$\mathrm{do}^{5}$. A partir da forma como se organizam e se estruturam, buscou perceber como se reproduzem e como se articulam para atender às novas necessidades socioculturais $\mathrm{e}$ ao ritmo de vida social. Assim, apresenta as formas tradicionais de educação tomando três rituais, Khêêntúwayê, Pepyê e Pepkah$\dot{a} k$, como importantes elementos para entender como os Canela internalizam em seus membros a sua maneira de ser, garantindo a sua sobrevivência enquanto grupo. Utiliza o mito de Awkhê como ferramenta de análise da relação Canela/escola, como elemento essencial para compreender a relação tensa que estabelecem com a alteridade. Desse modo, aborda o processo de escolarização visando, sobretudo, a entender o sentido e a importância que os Canela atribuem à escola e como se dá a relação entre os dois campos semânticos, o da escola e o dos povos indígenas.

Rodolpho Sá (2009) buscou compreender a relação dos Ràmkôkamẽkra/Canela com a educação escolar tomando como campo empírico a migração para a cidade em busca da escola. De acordo com Sá, o contexto das relações interétnicas coloca aos indígenas a "necessidade" de estudar. Como na aldeia só existe o ensino de $1^{\mathrm{a}}$ a $4^{\text {a }}$ séries, os Ràmkôkamẽkra/Canela buscam a cidade para dar continuidade aos estu- dos. 0 autor faz uma leitura dessa migração a partir da organização social Canela e de seus processos históricos, considerando suas narrativas e representações, e toma como eixo a narrativa acerca do herói cultural Awkê. Considera que os deslocamentos para estudar em centros urbanos podem ser compreendidos como uma possibilidade de reeditar a escolha ancestral, atuando a escola como lugar de aprendizado e formação corporal por meio de suas dinâmicas de disciplinamento.

Outro projeto desenvolvido no GPEMMP-UFMA, "Saúde indigenista e participação indígena”, financiado pela FAPEMA, reuniu investigações sobre as questões relacionadas ao atendimento à saúde dos povos indígenas e suas representações sobre o que denominamos saúde/doença.

A dissertação de Ana Caroline Amorim Oliveira (2008) consta de um estudo das práticas de tabu, em especial as de resguardo, na sociedade Ràmkôkamẽkra, enfatizando a proteção da saúde contra as substâncias poluentes presentes em determinados alimentos, no sangue menstrual e nas relações sexuais entre os membros dessa sociedade. Nesse sentido, discute a noção de corporeidade do povo Ràmkôkamẽkra, sintetizada pela categoria êmica corpo forte, isto é, um corpo construído com base no cumprimento dos resguardos a fim de evitar seu enfraquecimento e, consequentemente, a possibilidade de contrair doenças. Aponta para a importância dos resguardos no cotidiano desse

5. Essas pesquisas foram desenvolvidas durante a realização de um projeto de capacitação de professores indigenas canela, efetivada no âmbito do projeto "Põkrá Canela”, proposto pela Associação Comunitária Indigena Wôokrô (ACIW), patrocinado pela Inter American Foundation (IAF) em parceria com a Timbira Research and Education Foundation. Teve como colaboradores a Secretaria de Estado da Educação do Maranhão, a UFMA por meio do grupo de pesquisa Estado Multicultural e Políticas Públicas e a FUNAI. A participação nesse projeto favoreceu o contato dos pesquisadores com os professores indígenas. 
povo, perceptível, sobretudo, nos momentos de liminaridade: ritos de iniciação, menstruação, gravidez e pós-parto. A análise se desdobra abarcando ainda uma discussão sobre a relação entre o modelo terapêutico tradicional (composto de práticas preventivas e curativas) e o biomédico, situados em um contexto de intermedicalidade, tendo em vista as negociações e ressignificações das práticas dos sujeitos sociais neles envolvidos: indígenas, pajés, agentes indígenas de saúde e profissionais biomédicos.

Ainda no âmbito das relações dos Canela com os saberes médicos, foram realizadas outras investigações. Na sua dissertação, Carlos Lourenço de Almeida Filho (2016) procurou analisar como as ações de atenção à saúde e controle social são efetivadas junto aos Canelas. Para tanto, tomou como campo empírico o Distrito Sanitário Especial Indígena e, mais especificamente, o Polo-Base Barra do Corda, que coordena o atendimento ao povo Canela. Buscou entender como os Canelas percebem o que denominamos saúde e doença e em que medida as ações indigenistas levam em consideração os saberes canela. Posteriormente, o mesmo autor investigou o que denominou confronto entre conhecimentos canela e ocidentais no âmbito do corpo forte, em 2015. Analisou, então, os aspectos relacionados à noção de corpo forte construída pelos Canela a partir do estabelecimento do contato com o mundo não indígena. Segundo o autor, o contato favoreceu o surgimento de problemas que implicaram a necessidade da introdução de serviços biomédicos. Essa introdução efetivou-se respaldada em políticas indigenistas de saúde, que foram sendo reformuladas ao longo do tempo. 0 autor tomou como referência empírica o atendimento realizado para o povo Canela, observando as formas de transmissão de conceitos e práticas do sistema ocidental de saúde e quais têm sido os resultados desse processo. As observações foram feitas no Polo-Base de Barra do Corda, instância do Distrito Sanitário Especial Indígena situada na cidade de Barra do Corda - MA, próxima à terra indígena canela onde vive esse povo. 0 polo-base é analisado como espaço de fronteira, uma zona de contato, onde ocorrem confrontos, oposições, conflitos e ressignificações entre dois modelos distintos de se pensar a questão da saúde, por meio da intermedicalidade.

Rose Panet realizou duas investigações entre os Canela. Na primeira, procurou perceber como o espaço da aldeia Ràmkokamekra/Canela tem uma relação direta com a organização sociocultural, formando uma “morfologia social” (PANET, 2003). Em seu doutorado, voltou-se para a forma como os Canela percebem a sexualidade (PANET, 2010). Analisou as representações sobre a sexualidade canela a partir do cotidiano, privilegiando alguns rituais, algumas narrações mitológicas e, principalmente, a polifonia discursiva de homens e de mulheres a respeito do sexo. Procurou apontar a onipresença e a centralidade da sexualidade entre os Canelas e analisou a representação da sexualidade canela considerando, também, alguns rituais que propiciam o estabelecimento de padrões de sociabilidade. Procurou perceber como vivenciam a sexualidade, especialmente, pela prática do Krõõ jõ pi, uma das formas do sexo sequencial, e pelo discurso dos atores sociais sobre essa prática sexual, que acontece no final de três festas de caráter essencialmente masculino: o Kêtuajê, o Pêpjê e o Pepkahàc. Aponta que o corpo canela é moldado, construído, domesticado, e que a sexualidade se apresenta como tela na qual se imprimem representações sociais de inúmeras "dobraduras”, que se inserem em todos os domínios da vida, 
desde a construção da pessoa e sua identidade sexual, passando pelos processos de produção e manutenção da subsistência. Essa sexualidade concerne às pessoas e à intimidade de seu corpo, aos ingredientes desse corpo e a sua fecundidade. Nessa conjunção, a importância do corpo é antes de tudo ser um corpo sexuado, associado às imagens e representações sociais, sendo a partir de seu corpo sexuado e da sexualidade que homens e mulheres se definem.

Também tomando ritos canela como campo empírico, Nelma Rolande (2013) investigou o significado da prática de ornamentar corpos em diferentes contextos da sociedade canela, especialmente durante os ritos Ketuwajê e Pepjê (ritos de iniciação) e os ritos funerários. Analisou a ornamentação como parte do processo de fabricação do corpo canela e uma das estratégias de diferenciação na construção de corpos, servindo como elemento de legitimação do status de hamrén (posição social de prestígio) outorgada a alguns membros dessa sociedade. A construção de corpos diferenciados nos ritos de iniciação é reafırmada no tratamento dado a esses corpos ao fim da vida, nos ritos funerários. Os rituais são analisados como momentos privilegiados de instituição/consagração do corpo forte, que no contexto canela significa bonito, alegre, bom, sabido.

Ligia Raquel R. Soares (2010) abordou o universo cosmológico e a visão de mundo do povo Ràmkôkamẽkra/Canela como uma forma de buscar compreender como eles veem e interpretam o mundo. Enfatiza que a cosmologia, os mitos, os rituais e a musicalidade estão intrinsicamente interligados na visão de mundo desse povo. Em 2015, a mesma autora realizou uma etnografia do ritual de Pepcahàc à luz de uma abordagem etnomusicológica, descrevendo minuciosa- mente todas as fases do ritual e ligando-as aos sistemas e repertórios musicais existentes (SOARES, 2015).

Fisher (2014) realizou um estudo sobre a cultura material canela no qual analisa os itens colecionados pelo pesquisador alemão Fittkau entre esse povo. Procura mostrar que as tecnologias de "barulho" e de "silêncio" são utilizadas de forma alternada nos ritos de passagem. Interpreta esse movimento no contexto da socialização da classe de idade como um agente coletivo. Afirma que os objetos apontam a alternância de atividades coletivas com períodos prolongados de imobilidade e abstenção de certas práticas e de certos alimentos, mostrando que os mecanismos para fomentar o potencial individual estão replicados no nível coletivo. Considera que em qualquer tarefa masculina como caçar, cantar ou curar, a potência necessária para o sucesso da atividade requer a preparação com base em resguardos e restrições alimentares.

0 mesmo autor (FISHER, 2015a) mostra como a organização cerimonial dos Canela continua a mediar os contatos com a cidade e as regiões nos arredores da terra indígena (TI) Kanela. Uma análise baseada em tendências gerais, como taxa de emprego e escolaridade, faz sumir as causalidades que são consequências da operação e lógica de instituições indígenas. Fisher (2015b) também estudou as condições instáveis nas terras indígenas como fruto da política econômica de desenvolvimento do Brasil rural como um todo. Apesar de o "ordenamento territorial" ser promovido como uma forma de garantir a autonomia e a soberania indígenas, Fisher argumenta que as consequências dessa política muitas vezes têm resultados contrários ao bem-estar dos povos nas TIs.

Barros (2013, 2016) debruçou-se sobre a interface entre a antropologia visual e a 
memória social a partir das fotografias de Curt Nimuendajú que registram o Kokrit (festa das máscaras).

Teresa Müller (2015) realizou sua pesquisa de doutorado entre os Ràmkôkamẽkral Canela. Nesse trabalho, mostra como as perspectivas ligadas à ontologia e à cosmovisão indígena ajudam a entender como os Canela conservam a memória cultural e a biodiversidade. Ela estava especialmente interessada nas práticas ligadas à identificação e à manutenção de variedades no estoque das sementes mantido pelos Canela como parte de seu patrimônio cultural e herdado de uma parentela específica.

Algumas das pesquisas mais recentes abordam os Timbira de um modo geral. Bavaresco (2009) reflete sobre as potencialidades e limitações da metodologia de mapeamentos participativos enquanto ferramenta pedagógica na promoção do diálogo entre diferentes sistemas de conhecimento ambientais, notadamente o dos cupẽ (não indígenas) e dos mẽhi (indígenas). A pesquisa foi desenvolvida durante a execução de oficinas para jovens indígenas Timbira em um projeto desenvolvido pelo Centro de Trabalho Indigenista (CTI) de 2006 a 2007, no Centro Timbira de Ensino e Pesquisa Pinxwyj Himpejxà, em Carolina - MA.

Focalizando também os Timbira, Noleto (2009) analisou a questão do desenvolvimento sustentável envolvendo os Timbira representados pela Associação Wyty Catë das Comunidades Timbira do Maranhão e Tocantins. A autora utilizou como estudo de caso a Fruta Sã, pequena unidade fabril localizada em Carolina, sul do Maranhão, que produzia polpas de fruta do Cerrado por meio do extrativismo realizado por pequenos produtores rurais e por indígenas.

A Fruta Sã também foi campo empírico utilizado por Ana Carolina Cambeses $\mathrm{Pa}$ - reschi (2002) em sua tese de doutorado, defendida na UnB. A autora analisou a relação dos Krahô com os seus "vizinhos" não indígenas, mediada pela Fruta Sã.

Ainda abordando os Timbira de modo geral, a dissertação de Siqueira Junior (2007) analisa as práticas e representações dos grupos timbira em torno da Associação Wyty-Catë. Observa como se constituem as relações de alteridade e busca de unidade entre esses grupos timbira diante de outros grupos indígenas e de não índios com os quais se relacionam no campo político intersocietário. Analisa a perspectiva dos grupos timbira que a integram em relação às possibilidades de construção e mediação de uma unidade pan-Timbira e o papel daqueles que poderiam ser chamados de representantes desses grupos na associação.

Os Krikati, outro povo de língua Timbira, após as pesquisas de Newton (1974) e Lave (1967), foram mais recentemente investigados por Mirtes Barros. As duas investigações realizadas pela autora, a primeira no mestrado e a segunda no doutorado (BARROS, 1999, 2002), estiveram voltadas para a arte Krikati, tomando como campo empírico o ritual Wu'tú.

Kátia Correa (2000) analisou o processo de demarcação da terra Krĩkati, ocorrido num intervalo de vinte e cinco anos, que contou no seu final com a participação ativa dos Krikati, que assumiram seu protagonismo. Procurou identificar o campo de forças que se estabelece num processo de demarcação de terra indígena, analisando a disputa pelo poder de afirmar os limites do território. Segundo a autora, índios e "brancos" vivenciaram diferentes situações ao longo do processo, marcadas ora por relações de conflito, ora por relações de aliança, alternando momentos de conflito e de trégua. Aponta que as estratégias 
utilizadas e o posicionamento dos atores do processo, índios Krīkati, fazendeiros, órgãos públicos, variou ao longo do tempo. 0 órgão indigenista do Estado, a FUNAI, oscilou entre posições favoráveis aos índios, com respeito à sua cultura e ao seu território, e posições favoráveis aos fazendeiros, sob o argumento de que o território pleiteado pelos índios era demasiado. Os Krĩkati utilizaram-se basicamente de estratégias simbólicas, apoiadas na força que a questão indígena assumiu internacionalmente e no direito imemorial dos índios à terra. Ameaçaram a deflagração de uma guerra contra os "brancos". A dinâmica da disputa encerrou contradições e ambiguidades da parte de todos os atores envolvidos.

Durante o mestrado, Correa (2002) buscou compreender como se dá a construção da especificidade Krĩkati, levando em conta que a identidade krîkati vem se construindo ao longo de sua existência, primeiramente quando o contato/a interação desse povo se limitava a outros povos indígenas e posteriormente quando entrou no âmbito do contato/da interação com o "branco". As reflexões tomam como ponto de partida as primeiras fontes históricas referentes aos Krikati, por volta de meados do século XIX, e finalizam com um mapeamento atual dessa sociedade, procurando pontuar as principais compulsões que vão redefinindo, continuamente, esse povo.

A mesma autora, em sua tese de doutorado (CORREA, 2016), analisou a dinâmica da mobilidade krikati tomando como referência as narrativas desse povo que se referem aos movimentos de "espalhar" e "ajuntar”. Tomou essa dinâmica como eixo para discutir os vários sentidos que os Krîkati atribuem às formas de mobilidade dentro do seu território, apontando suas motivações para permanecer juntos em uma "al- deia grande", bem como para se "espalhar" construindo aldeias "novas”. Procurou perceber como os Krikati constroem suas relações interpessoais e como procuram construir alternativas às estruturas sociais para atingir seus objetivos. Partindo das narrativas que atualizam o mito da "aldeia grande”, discutiu como vem se (re)construindo a mobilidade e as relações krĩkati diante de uma terra demarcada pelo Estado, ato que impõe limites a essa mobilidade. 0 Estado, ao demarcar a terra indígena Krĩkati, desconsidera lugares ocupados anteriormente à demarcação, forçando os Krĩkati a estabelecer novas relações com outros lugares e construir novas territorialidades na terra demarcada. $\mathrm{Na}$ análise, a autora procurou considerar a dinâmica da mobilidade no contexto do exercício de dominação/colonialidade exercidas pelo Estado brasileiro sobre os povos indígenas, sem desconsiderar os modos nativos de reflexividade e criatividade dos Krikkati de ocupar a terra que se faz território. Privilegiou as narrativas dos interlocutores krĩkati, fazendo uso também de produções antropológicas sobre esse povo e sobre outros povos timbira, assim como de documentos relativos ao processo demarcatório.

0 povo Krîkati foi investigado também por Julia Miras (2016). A referida autora, em sua dissertação, tratou do processo de demarcação da terra indígena (TI) Krĩkati, propondo uma reflexão sobre os sentidos e consequências da demarcação de uma terra indígena, entendida como um movimento que esquadrinha a terra (ou Terra) segundo a lógica proprietária característica da perspectiva moderno-ocidental. Por meio de uma etnografia dos laudos de identificação que compõem o processo demarcatório realizado pela FUNAI, acompanhou as ações engendradas pelos documentos para 
estabilizar as fronteiras e eclipsar a multiplicidade presente na(s) terra(s) indigena(s). Ao longo do trabalho, destaca as ações dos indios e seus impactos na constituição dessa(s) terra(s). Provoca, também, uma reflexão sobre o papel que os antropólogos podem exercer nos processos de demarcação.

Sobre o povo Krahô, foram realizadas algumas investigações após a clássica etnografia de Melatti (1974). Julio César Borges (2004) debruçou-se sobre a categoria tempo entre os Krahô, discutindo como percebem o tempo. Com base em uma etnografia, afirma que o tempo para os Krahô é pensado especialmente nos ciclos das atividades cotidianas que envolvem os mitos. Essa ideia de tempo determina quais cantos e danças podem ser realizados, assim como as atividades econômicas e os tipos de corrida de tora. Em sua tese de doutorado (BORGES, 2014), o pesquisador tomou como ponto central os amji kin nos processos de resistência étnica dos Krahô.

Melo (2010) analisou o "drama social" que envolveu os Krahô e o Museu Paulista da Universidade de São Paulo (USP), com base na ação de um grupo de indígenas krahô que, em 1986, se organiza para reivindicar a devolução de uma machadinha (kàjré) que estava sob a guarda do Museu Paulista da USP e que havia sido doada à instituição pelo antropólogo Harold Schultz em 1947.

A relação entre Hotxwa, Festa da Batata e o Riso foi trabalhada por Ana Gabriela Morim Lima (2010) em sua dissertação de mestrado. Em sua tese de doutorado (LIMA, 2016), a pesquisadora abordou a questão do cultivo da batata, gênero e ritual entre os Krahô.

0 trabalho de Figueiredo Júnior (2015) inaugura a investigação, no Maranhão, sobre processos de etnogênese. Sua disserta- ção analisa a "trajetória" dos Krenyê após a perda de seu território, focando nos processos que marcam a história desse grupo e nas relações que vão se construindo de modo a se rearticular e iniciar um processo de reversão da espoliação sofrida em luta por reconhecimento e resistência. Passam a reivindicar do Estado direitos territoriais e étnicos.

\section{Novos olhares sobre os Timbira}

Novas investigações sobre os Timbira foram concluídas recentemente e outras se encontram em andamento. 0 mais importante a destacar é que o novo cenário é marcado, também, pela produção de pesquisadores timbira que estão se graduando e pós-graduando em diferentes instituições de ensino superior.

Ao longo do ano de 2017, dois pesquisadores krahô apresentaram suas dissertações de mestrado. Renato Yahe Kraho, no Programa de Mestrado em Ensino de Línguas, na Universidade Federal do Tocantins (campus de Araguaína), abordou o projeto político-pedagógico da Escola 19 de Abril, da aldeia Manuel Alves, e Creuza Prumkwyj Krahô (2017), no Mestrado Profissional em Sustentabilidade junto a Povos e Territórios Tradicionais da UnB, com a dissertação Wato ne hômpu ne kãmpa: convivo, vejo e ouço a vida Mehi (Mãkrarè), aborda a percepção feminina krahô sobre o processo de resguardos.

Cassiano Sotero Apinagé defendeu, em dezembro de 2017, sua dissertação sobre Escola, Conhecimentos e Território entre os Apinajé, abordando a relação entre processo de educação escolar e conhecimentos sobre o território tradicional. Cabe destacar que outro Apinajé, Julio Kamer Ribeiro Apinage, e uma Krahô, Leticia Jonkwakwyj, estão 
fazendo mestrado em Antropologia na Universidade Federal de Goiás.

Esses pesquisadores podem estar atendendo ao apelo emocionante que Julio Cesár Melatti fez aos indígenas durante o VI Seminário Timbira, no qual estava presente como convidado ${ }^{6}$. Em seus comentários das apresentações realizadas no referido seminário, Melatti afırmou que gostaria muito de ver a reação de Roberto DaMatta ao ouvir um Apinajé citando Rousseau (referindo-se à apresentação de Cassiano Sotero Apinagé). Esse comentário expressava o quanto estava impressionado com o avanço do processo de escolarização dos índios e como isso fazia diferença tanto nas etnografias produzidas sobre eles quanto nas etnografias que eles começam a produzir sobre si mesmos. Instigou os pesquisadores indígenas timbira a não reproduzir, por inteiro, as obras etnográficas sobre eles, que foram feitas por pesquisadores não indígenas, mas apropriar-se criticamente desses textos, inclusive do texto do próprio Melatti (sobre os Krahô), assim como de DaMatta e de Giraldin (ambos sobre os Apinajé), sugerindo interpretações alternativas ou até outros caminhos de análise.

As reflexões realizadas por essas dissertações de autoria indígena potencializam a realização de uma antropologia reversa, uma antropologia simétrica ou mesmo uma antropologia exegética, conforme expresso no artigo de Odair Giraldin e Cassiano Sotero Apinage, presente neste volume, no qual os próprios pesquisadores indígenas interpretam criticamente suas tradições culturais.

Atualmente há dois pesquisadores estudando os Krahô: Ian Packer, na Unicamp, que se debruça sobre oratórias e lideranças, e Eduardo Santos Goncalves Monteiro, na Universidade de São Paulo, com etnografias de rituais, sobretudo o ritual de Pepcahàc nos Krahô. Ambos participaram do VI Seminário Timbira.

Entre os Apinajé há duas pesquisadoras indígenas, Welitania e Lidiane, alunas egressas do curso de Ciências Sociais da UFT (campus de Tocantinópolis) e mestrandas em Antropologia Social na UnB, realizando pesquisas sobre lideranças femininas e educação escolar indígena, respectivamente. Ambas estiveram no VI Seminário Timbira.

Odair Giraldin e Ligia Raquel Rodrigues Soares desenvolvem pesquisas e registros sobre a musicalidade timbira, dentro de projeto desenvolvido no âmbito do Instituto Nacional de Ciência e Tecnologia (INCT) Brasil Plural.

Também ao longo de 2017 foram concluídas, no âmbito da UFMA, duas investigações voltadas para povos timbira, sendo uma sobre os Pyhcop catiji e outra sobre os Kreyê. A primeira, de autoria de Maycon Franzoi de Melo, trata da nominação "gavião" em dois momentos de um mesmo processo: o nome como constituinte das relações que constroem pessoas e valores morais por meio da transmissão de nomes e o nome como "roupa", pele que recobre a superfície do corpo do iniciado no contexto cerimonial por meio de objetos ritualísticos que possuem capacidade de produzir e transformar os corpos e o cosmos gavião. 0 eixo dessa etnografia é o ritual de máscaras Wyty, que envolve a partir de metades e grupos cerimoniais indivíduos e grupos locais diferentes em uma grande produção de no-

6. Veja neste dossiê a transcrição do pronunciamento avaliativo de Melatti sobre o Seminário. Ver também a entrevista (Dos polos de articulação às Redes de Relações) concedida por ele a André Demarchi e Odilon de Morais durante o VI Seminário, também presente neste dossiê. 
mes e corpos. Procura identificar as transações com outros índios ( $m e$ hẽeh $=$ me, pron. plural, pessoas, + hẽeh, s., carne) e com estrangeiros de diferentes matrizes, especialmente animais selvagens (pryyhre), com os quais, a partir desse ritual, os Gavião podem criar afınidades necessárias para prosperar no intento de produzir nomes e corpos. Essa tese constitui-se na primeira etnografia sobre os Pyhcop catiji, e o segundo trabalho, após o de Maria Helena Barata (1981), a ser produzido sobre esse povo.

A investigação sobre os Krenyê de autoria de Mônica Ribeiro Moraes de Almeida (2017) aborda a dinâmica de reorganização social desse povo, que desde o início do século XXI começa a afirmar pertencimento aos considerados extintos Krenyê de Bacabal. Em decorrência da invasão do seu território por forças coloniais, passaram por processos de dispersão e fragmentação que os levaram a viver nas terras de outros povos em situação de "invisibilidade" e silenciamento. A autora enfatiza o caráter histórico e transitório das identidades e as questões políticas e estratégicas Krenyê, que são postas pela necessidade de reconhecimento identitário e territorial. Trata-se de um trabalho muito original, pois as dinâmicas de emergência étnica no Maranhão passaram a ter visibilidade na segunda década do século XXI e ainda não haviam sido objeto de investigação. Apesar de mostrar que o processo de emergência étnica não envolve todos os descendentes daqueles que se afirmam os Krênyê históricos, que incluem pessoas oriundas de vários povos, o trabalho mostra que o antigo sistema de relações interétnicas entre povos da região criou uma matriz cultural indígena que ainda serve para situar relações de parentesco e comunidades hoje, mesmo em casos em que "o povo" em questão não é reconhecido pelo Estado.
Esse "ecossistema" histórico de relações indígenas continua e pode criar nódulos para a recristalização de identidades e a geração de novas territorialidades. Pode até ganhar feições jurídicas, com o seu reconhecimento pelo Estado.

0 dossiê que agora apresentamos é constituído pelas investigações mais recentes que foram objeto de discussão na sexta edição do Seminário Timbira e que estão relacionadas a diferentes temáticas e a diferentes povos Timbira. A questão dos etnônimos foi trazida à discussão, no referido seminário, especialmente pelos Ràmkôkamẽkra, e é abordada no artigo de Soares e Melo intitulado "Redes de relações timbira: estudos de caso a partir dos etnônimos em uso pelos Ràmkôkamẽkra/Canela e os Gavião Pyhcop catiji”.

Os problemas relacionados à luta pela terra foram objeto de análise de dois artigos. 0 de autoria de Monica Almeida e João Damasceno Figueiredo Junior discute como a luta pela terra se constitui um elemento fundamental ao processo de reconhecimento étnico que vem sendo empreendido pelos Krenyê, que de certa forma inauguram, no Maranhão, a investigação sobre processos que foram denominados por Oliveira (1999) "emergência étnica".

0 segundo artigo sobre a questão territorial, produzido por Katia Corrêa e Julia Miras, analisa a dinâmica Krĩkati de habitar a terra a partir da demarcação, tomada como um acontecimento que age na terra buscando perceber o impacto que a não desintrusão gera em suas vidas. Coloca a regularização fundiária em perspectiva para compreender como os procedimentos de criação de uma terra indígena (TI), assim como a própria categoria de TI, são exógenos aos povos indígenas que vivem e se relacionam de outros modos com a terra. Aponta como a vida e a 
terra estão interconectadas e que, portanto, a demarcação é fundamental para garantir o direito à vida dos povos. Traça uma breve etnografia dos percursos do processo e da morosidade do Estado em garantir o cumprimento dos direitos indígenas, mostrando como estes tantas vezes aparecem como um "faz de conta" construído pelo próprio Estado e continuamente desvelado pelos índios.

A construção do corpo canela é abordada no artigo de Ana Caroline Oliveira e Josinelma Rolande. As autoras procuram mostrar como a construção da corporeidade entre os Canela se dá especialmente nos ritos de iniciação, menstruação, gravidez e pós-parto. 0 artigo apresenta as práticas de tabu, resguardo, restrição e ornamentação do corpo canela, afırmando que a corporeidade dos Canela é engendrada coletivamente por meio da consubstancialidade, isto é, os indivíduos de uma mesma família acreditam possuir a mesma substância (sangue). Os tabus, resguardos e restrições materializados nas práticas cotidianas demonstraram uma forma de manutenção da saúde e do corpo canela. As autoras concluem apontando que a expressão "fıcar bonito", utilizada pelos Canela como justificativa para pintar seus corpos, traz implícito o sentido de agir, isto é, como a pintura corporal age sobre os corpos fazendo-os sabidos, endurecidos, saudáveis, bonitos. Assim, na construção do corpo canela, um objetivo pode ser apontado como comum: o corpo "tem que ficar bonito", entendendo-se "ficar bonito" como um "corpo alegre”, "sabido", enfim, um corpo forte.

A relação dos Timbira com a escolarização está presente no artigo de Odair Giraldin e Cassiano Sotero Apinagé, que resultou de pesquisas realizadas por este último. Como um membro do povo Apinajé, Cassiano busca refletir sobre narrativas de membros do seu povo, tomando como referência a memória dos anciãos com quem tem dialogado. Nesse diálogo, aborda o modo de vida, as formas de ocupação do território e também o processo de aprendizagem praticado no passado e na atualidade entre os Apinajé. Pratica, dessa forma, uma reflexão que podemos chamar de antropologia simétrica, fazendo descrição e reflexão sobre seu próprio referencial cultural e teórico.

0 dossiê traz ainda artigos de convidados, também pesquisadores dos povos Timbira, que não estiveram presentes no VI Seminário. 0 primeiro artigo é uma parceria entre Maxwell Miranda, Edivaldo Wakê Krahô e Letícia Jôkàhkwỳj Krahô. Nele, aborda-se a onomástica Krahô, fazendo uma descrição do sistema de nominação, apontando os nomes e suas referências dentro do amplo sistema de metades e grupos cerimoniais Krahô, além de se analisar o discurso realizado no ritual de nominação.

0 segundo é o artigo escrito por Bruno Nogueira Guimarães. Em seu texto, Bruno aborda a questão da relação interétnica dos Apànjekra/Canela com não indígenas dentro e fora do contexto da aldeia. 0 autor reflete sobre isso a partir de sua experiência de campo ao ser levado a produzir textos e sobretudo projetos para os Apànjekra. A partir dessa situação, reflete sobre a relação dos Apànjekra com a escola e com os conhecimentos não indígenas como estratégias para fazer frente ao contexto interétnico.

Além dos artigos, apresentamos uma entrevista realizada com Júlio Cesar Melatti por André Demarchi e Odilon Morais durante a realização do VI Seminário Timbira. Um dos temas da entrevista está relacionado à criação e manutenção da "página do Melatti”, um site na internet no qual o pesquisador disponibiliza boa parte de suas notas de campo, genealogias de parentesco, 
contos de guerra e fragmentos biográficos dos índios Krahô, além de artigos, resenhas e seu seminal projeto sobre as "Áreas etnográficas da América Indígena”. A entrevista é seguida de um pequeno texto, "Da antropologia como corrida de tora”, proferido no encerramento do referido evento, produzido em diálogo intercultural com os Timbira e demais pesquisadores presentes, que lança algumas respostas às incontáveis perguntas apresentadas pelos pesquisadores timbira durante o evento.

\section{Referências}

ALMEIDA, C. M. de. A Carolina ou a definitiva fixação de limites entre as províncias do Maranhão e Goyaz. Rio de Janeiro: Typ. Episcopal de Agostinho de Freitas Guimarães, 1852.

ALMEIDA, M. R. M. de. A gente vivia detrás dos outros. 2017. Tese (Doutorado) - Programa de Pós-Graduação em Ciências Sociais, Universidade Federal do Maranhão, São Luís, 2017.

ALMEIDA FILHO, C. L. de. 0 confronto entre conhecimentos Canela e ocidentais no âmbito do corpo forte. 2016. Dissertação (Mestrado em Antropologia Social) - Universidade Federal do Pará, Belém, 2016.

APINAGÉ, C. S. Escola, meio ambiente e conhecimentos: formas de ensinar e aprender na teoria e na prática entre os Apinajé. 2017. Dissertação (Mestrado em Ciências do Ambiente) -Universidade Federal do Tocantins, Palmas, 2017.

ÁVILA, T. A. M. de. "Não é do jeito que eles quer. É do jeito que nós quer": os Krahô e a biodiversidade. 2004. Dissertação (Mestrado) - Universidade de Brasília, Brasília, 2004.

AZANHA, G. A forma Timbira: estrutura e resistência. 1984. Dissertação (Mestrado) -Programa de Pós Graduação em Antropologia, Universidade de São Paulo, São Paulo, 1984.
BARATA, M. H. Os Pukobyê e os Kupen: análise de um drama. 1981. Dissertação - Programa de Pós-graduação em Antropologia, Universidade de Brasília, Brasília, 1981.

BARROS, M. M. dos S. Wu'tú: o ritual artístico (re)criador da etnicidade krikati. 1999. Dissertação (Mestrado) - Programa de Pós-Graduação em Sociologia Universidade Estadual Paulista Júlio de Mesquita Filho, Araraquara, 1999.

BARROS, M. M. dos S. A arte Krikati: uma abordagem sociológica. 2002. Tese (Doutorado) - Programa de Pós-Graduação em Sociologia, Universidade Estadual Paulista Júlio de Mesquita Filho, Araraquara, 2002.

BARROS, N. A. de. Tudo isso é bonito! 0 festival das máscaras Ràmkôkamekra: imagem, memória, Curt Nimuendajú. 2013. Dissertação (Mestrado) Universidade Federal de Pernambuco, Recife, 2013.

BARROS, N. A. de. Os Ramkokamekrá-Canela e as fotografias da Coleção Carlos Estevão de Oliveira. In: ATHIAS, R.; GOMES, A. Coleções etnográficas, museus indígenas e processos museológicos. Recife: Editora da UFPE, 2016.

BAVARESCO, A. A. 0 pjê e a cartografia: os mapeamentos participativos como ferramenta pedagógica no diálogo entre saberes ambientais. 2009. Dissertação (Mestrado) - Programa de Pós-Graduação em Desenvolvimento Sustentável, Universidade de Brasília, Brasília, 2009.

BORGES, J. C. 0 retorno da velha Senhora ou a categoria de tempo entre os Krahô. 2004. Dissertação (Mestrado) - Programa de Pós-Graduação em Antropologia Social, Universidade de Brasília, Brasília, 2004.

BORGES, J. C. Feira Krahô de sementes tradicionais: cosmologia, história e ritual no contexto de um projeto de segurança alimentar. 2014. Tese (Doutorado) - Programa de Pós-Graduação em Antropologia Social, Universidade de Brasília, Brasília, 2014.

BOURDIEU, Pierre. 0 poder simbólico. Lisboa: Difel, 1989. 
COIMBRA JR., C. E. A. et al. The Xavante in transition: health, ecology, and bioanthropology in central Brazil. Ann Arbor: University of Michigan Press, 2004.

CORREA, K. N. F. Muita terra para pouco indio?: 0 processo de demarcação da terra indígena Krikati. São Luís: EDUFMA, 2000.

CORREA, K. N. F. A política indigenista nas relações interétnicas: a construção de um território indígena. 2002. Dissertação (Mestrado) - Universidade Estadual Paulista Júlio de Mesquita Filho, 2002.

CORREA, K. N. F. AJCRỲ/COHPRÕ: dinâmicas de "espalhar" e "ajuntar" no território Krîkati. 2016. Tese (Doutorado) - Programa de Pós-Graduação em Ciências Sociais, Universidade Federal do Maranhão, São Luís, 2016.

CROCKER, W. 0 Movimento Messiânico dos Canelas: uma introdução. In: SHADEN, E. Leituras de etnologia indígena. São Paulo: CEN, 1976.

CROCKER, W. H. The Canela (Eastern Timbira), I: an ethnographic introduction. Washington: Smithsonian Contributions to Anthropology, n. 33, 1990.

CUNHA, M. C. da. Os mortos e os outros: uma análise do sistema funerário e da noção de pessoa entre os índios Krahô. São Paulo: Hucitec, 1978.

DAMATTA, Roberto. Ensaios de antropologia estrutural. Petrópolis: Vozes, 1973.

DAMATTA, Roberto. Um mundo dividido: a estrutura social dos índios apinayé Petrópolis: Vozes, 1976

FERGUSON, R. B.; WHITEHEAD, N. L. (Eds.) War in the tribal zone: expanding states and indigenous warfare. Santa Fe: School of American Research Press, 1991.

FERRAZ, I. Os Parkatêjê das matas do Tocantins: a epopeia de um líder Timbira. 1984. Dissertação (Mestrado em Antropologia) - Universidade de São Paulo, São Paulo, 1984.

FIGUEIREDO JÚNIOR, J. D. G. "Queremos dizer para o Brasil inteiro que nós estamos vivos e existimos": o processo de afırmação étnica e a luta por território dos Krenyê no Maranhão. 2015. Dissertação (Mestrado) - Programa de Pós-Graduação em Cartografia Social e Política da Amazônia, Universidade Estadual do Maranhão, São Luís, 2015.

FISHER, W. H. Die Ramkôkamekra canela aus Zentral-Maranão Brasilien. In: HERZOG-SCHRÖDER, Gabriele (Ed.) Von der Leidenschaft zu finden: Die Amazonien-Sammlung Fittkau. Munich: Museum fünf Kontinente, 2014. p. 111-120.

FISHER, W. H. Social Organization as the framework for interpreting demographic Measures of Urban Emigration among the Canela of South Central Maranhão, Brazil. Journal of Latin American and Caribbean Anthropology, v. 20, n. 1, p. 34-56, $2015 a$.

FISHER, W. H. Victims of the economic miracle forty years later: Brazil's indigenous lands in the post-earth summit era. Urban Anthropology and Studies of Cultural Systems and World Economic Development, v. 44, n. 3-4, p. 197-260, 2015b.

GIRALDIN, 0. Axpên Pyràk: história, cosmologia, onomástica e amizade formal Apinajé. 2000. Tese (Doutorado) - Departamento de Antropologia do Instituto de Filosofia e Ciências Humanas, Universidade Estadual de Campinas, Campinas 2000.

GOMES, F. E. B. Das "Trevas" à "Luz": os Canela a caminho do "desenvolvimento sustentável”. 2007. Dissertação (Mestrado) - Programa de Pós-Graduação em Ciências Sociais, Universidade Federal do Maranhão, São Luís, 2007.

GUIMARÃES, B. N. Os caminhos da terra indigena dos Canelas: história e transformações. 2012. Dissertação (Mestrado) - Programa de Pós-Graduação em Antropologia Social, Universidade Federal do Rio de Janeiro, Rio de Janeiro, 2012.

GUIMARÃES, B. N. 0 outro lado da moeda: dos benefícios sociais dos brancos ao parentesco dos Apanjekra. 2017. Tese (Doutorado) - Programa de Pós-Graduação em Antropologia Social, Universidade Federal do Rio de Janeiro, Rio de Janeiro, 2017. 
KRAHÔ, C. P. Wato ne hômpu ne kãmpa: convivo, vejo e ouço a vida Mehi (Mãkrarè). 2017. Dissertação (Mestrado em Desenvolvimento Sustentável de Povos Tradicionais) - Universidade de Brasilia, Brasília, 2017.

KOWALSKI, A. Tu és quem sabe: Aukê e o mito canela de ajuda aos índios. Brasília: Paralelo 15, 2008.

LIMA, A. G. M. Hoxwa: imagens do corpo, do riso e do outro. Uma abordagem etnográfica dos palhaços cerimoniais Krahô. 2010. Dissertação (Mestrado em Antropologia Social) -Universidade Federal do Rio de Janeiro, Rio de Janeiro. 2010.

LIMA, A. G. M. "Brotou batata para mim": cultivo, gênero e ritual entre os Krahô (TO, Brasil). 2016. Tese (Doutorado) - Programa de Pós-Graduação em Antropologia Social, Universidade Federal do Rio de Janeiro, Rio de Janeiro, 2016.

MACENA, J. M. de 0. "Isso é coisa de vocês": os índios Canela e a escola. 2007. Dissertação (Mestrado) - Programa de Pós-Graduação em Antropologia, Universidade de Brasília, Brasília, 2007.

MATTOS, R. J. da C. Chorographia histórica da Província de Goyáz. Revista do Instituto Histórico e Geográfico, v. 37, n. 1, p. 213-398, 1875.

MELATTI, J. C .0 Messianismo Krahó. São Paulo: Herder, 1972;

MELO, J. H. T. de L. Kajré: a vida social de uma machadinha Krahô. 2010. Dissertação (Mestrado) Programa de Pós-Graduação em Antropologia Social, Universidade Federal do Rio Grande do Norte, Natal, 2010.

MEHRINGER, J.; DIECKERT, J. Die Körper: und Wesensauffassung bei den brasilianischenmischen $\mathrm{Ca}-$ nela-Indianern. Zeitschrift für Ethnologie, Berlin, v. 115, p. 241-259, 1990.

MEHRINGER, J.; DIECKERT, J. Gemeinschaft, Gleichheit und Gegenseitigkeit: Die grundlegenden sozialen Prinzipien der Canela-Indianer Nordost-Brasiliens. Basessler-Archv, Berlin, Neue Folge, XL, p. 221-239, 1992.

MEHRINGER, J.; DIECKERT, J. Laufen für den Fortbestand der Welt: Der Klotzlauf bei den brasilia- nischen Canela-Indianern aus epischer Sicht. Indiana, Berlin, v. 13, p. 151-169, 1993.

MIGNOLO, W. Histórias locais/projetos globais: colonialidade, saberes subalternos e pensamento liminar. Belo Horizonte: UFMG, 2003.

MILLER, T. L. Bio-sociocultural aesthetics: indigenous Ramkokamekra-Canela gardening practices and varietal diversity maintenance in Maranhão, Brazil. 2015. Dissertation (D Phil.) - University of 0xford, Oxford, 2015.

MIRAS, J. De terra(s) indigena(s) à Terra Indigena: o caso da demarcação Krĩkati. 2015. Dissertação (Mestrado em Antropologia Social) - Universidade de Brasília, Brasília, 2015.

NASCIMENTO, A. Prwncwyj: drama social e resolução de conflito entre os Apãnjekra Jê-Timbira. 2009. Dissertação (Mestrado) - Programa de PósGraduação em Antropologia Social, Universidade Federal do Rio Grande do Norte, Natal, 2009.

NIMUENDAJÚ, C. U. Os Timbira Orientais. Belém: [s.n.], 1944.

NOLETO, J. A. A fábrica é dos mehin: desenvolvimento sustentável e povos indígenas vistos a partir do caso da Fruta Sã. 2009. Dissertação (Mestrado) - Programa de Pós-Graduação em Desenvolvimento Sustentável, Universidade de Brasília, Brasília, 2009.

OLIVEIRA, A. L. R. de. Messianismo canela: entre o indigenismo de Estado e as estratégias do desenvolvimento. 2006. Tese (Doutorado em Políticas Públicas) - Universidade Federal do Maranhão, São Luís, 2006.

OLIVEIRA, A. C. A. Ritos, corpos e intermedicalidade: uma análise dos resguardos de proteção entre os Ràmkôkamẽkra/Canela. 2002. Dissertação (Mestrado) - Programa de Pós-Graduação em Antropologia, Universidade Federal de Pernambuco, Recife, 2002.

OLIVEIRA, J. P. Uma etnologia dos índios misturados: situação colonial, territorialização e fluxos culturais. In: . (Org.). A viagem de volta. Rio de Janeiro: Contra Capa, 1999. 
PANET, R. L'Espace du Village Ramkokamekra et ses Corrélations avec son Cadre Sociocuturel. 2003. Dissertação (Mestrado em Antropologia Social e Etnologia) - École des Hautes Études en Sciences Sociales, Paris, 2003.

PANET, R. I-mã a kupên prãm !? Prazer e sexualidade entre os canelas. 2010. Tese (Doutorado) Programa de Pós-Graduação em Políticas Públicas, Universidade Federal do Maranhão, São Luis/École Pratique des Hautes Études, Paris, 2010.

PARESCHI, A. C. C. Desenvolvimento sustentável e pequenos projetos: entre o projetismo, a ideologia e as dinâmicas sociais. 2002. Tese (Doutorado) - Programa de Pós-Graduação em Antropologia, Universidade de Brasília, Brasília, 2002.

POSEY, D. A. Indigenous knowledge and development: an ideological bridge to the future? Ciência e Cultura, v. 35, n. 7, p. 877-894, 1983.

RIBEIRO, F. de P. Memória sobre as nações gentias que presentemente habitam o continente do Maranhão: análise de algumas tribos mais conhecidas: processo de suas hostilidades sobre os habitantes, causas que lhes têm dificultado a redução, e único método que seriamente poderá reduzi-las. Revista Trimensal de História e Geographia/Jornal do Instituto Histórico e Geographico Brasileiro, Rio de Janeiro, tomo 3, n. 10, 1841.

RIBEIRO, D. Os índios e a civilização. Petrópolis: Vozes, 1979.

ROCHA, R. P. A questão de gênero na etnologia Jê a partir de um estudo sobres os Apinaje. 2002. Dissertação (Mestrado) - Universidade Estadual de Campinas, Campinas, 2002.

ROCHA, R. P. 0 “Tempo do primeiro" e o "tempo de agora”: transformação social e etnodesenvolvimento entre os Apinaje/TO. 2012. Tese (Doutorado) - Universidade Estadual de Campinas, Campinas, 2012.

ROLANDE, J. Moços os feitos, moços bonitos?: a ornamentação na prática Canela de construir corpos bonitos e fortes. 2013. Dissertação (Mestrado em Ciências Sociais) - Programa de Pós-Graduação em Ciências Sociais, Universidade Federal do Maranhão, São Luís, 2013.
SÁ, R. "Nunca deixamos de ser índios": educação escolar e experiência na (da) cidade entre os Ramkokamekra Canela. 2009. Dissertação (Mestrado) Programa de Pós-Graduação em Antropologia Social, Universidade Federal do Rio Grande do Norte, Natal, 2009.

SIQUEIRA JUNIOR, Jaime. Wyty-Catë: cultura e política de um movimento pan-Timbira. 2007. Tese (Doutorado) - Programa de Pós-Graduação em Antropologia, Universidade de Brasília, 2007.

SOARES, L. R. R. Amji kĩn e pjê cunẽa: cosmologia e meio ambiente para os Ràmkôkamekrá/Canela. 2010. Dissertação (Mestrado) - Programa de Mestrado em Ciências do Ambiente, Universidade Federal do Tocantins, Palmas, 2010.

SOARES, L. R. R. "Eu sou o gavião e peguei a minha caça”: o ritual Pep-cahàc dos Ràmkôkamẽkra/ Canela e seus cantos. 2015. Tese (Doutorado) - Programa de Pós-Graduação em Antropologia Social, Universidade Federal do Amazonas, Manaus, 2015.

TEDLOCK, D.; MANNHEIM, B. (Eds.). The dialogic emergence of culture. Urbana: University of Illinois Press, 1995. 
